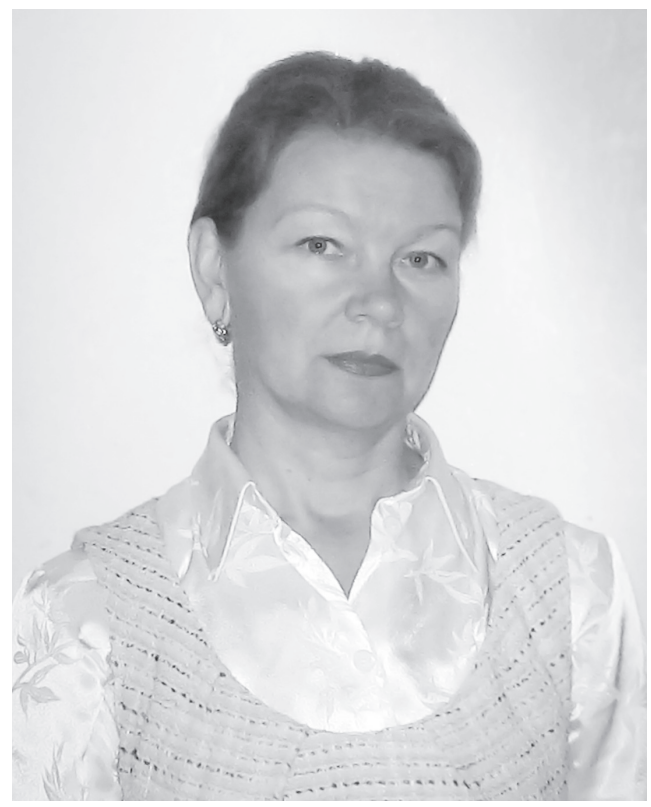

UDC:316.772.4

DOI: https://doi.org/10.32689/26172224-2019-18-3-198-211

Ievdokymova Valentyna Volodymyrivna, candidate of sociological sciences, Associated Professor, Open international university of human development "Ukraine", 03115, Kyiv, Str. L'vivs'ka, 23, tel.: +38 05044072 24, e-mail:evvv@evdokimova.kiev.ua ORCID: 0000-0002-0468-613X

Свдокимова Валентина Володимирівна, кандидат соціологічних наук, доцент кафедри сочіальної роботи та педагогіки, Інститут соціальних технологій Відкритого міжнародного університету розвитку людини "Україна", 03115, м. Київ, вул. Львівська, 23, тел.: +38050440 72 24, e-mail:evvv@evdokimova.kiev.ua

ORCID: 0000-0002-0468-613X

Евдокимова Валентина Владимировна, кандидат сочиологических наук, доцент кафедры сочиальной работы и педагогики, Институт социальных технологий Открытого международного университета развития человека “Украина", 03115, г. Киев, ул. Львовская, 23, тел.: +38 05044072 24, e-mail:evvv@evdokimova.kiev.ua

ORCID: 0000-0002-0468-613X

\title{
ARCHETIPICAL MODELS OF SUSTAINABLE DEVELOPMENT OF COUNTRIES: COMPARATIVE ANALYSIS
}

Abstract. The main features of a balanced approach to meeting their own needs from the point of view of "sustainable development" are considered. It is emphasized that the organization of provision of communal services is a basic need of every citizen and, according to the concept of rational bureaucracy, M. Weber, should work to meet the needs of each citizen. It is emphasized that developed European countries devote considerable attention to the quality of life of the population.

In particular, the city of Vienna (Austria) for the tenth consecutive year is ranked first in the quality of life rating. The archetypal dimension of the formation of a quality component of the supply of communal services in developed countries of Europe is briefly reviewed. Among them, Germany, which until 2006 formed a modern market for quality public utilities based on free competition. One of the 
peculiarities of the organization of the supply of housing and communal services in Germany has been the ease of transition from one service provider to a more acceptable one. The experience of Germany in the arrangement and retrofitting of old houses of the Khrushchev type in East Berlin is distinguished for prestigious and elite.

Modern German-quality approaches are designed to ensure that Germany becomes a country without "harmful energy" from 2020, namely, it will turn to new energy saving technologies that are affordable for middle class people. The market for communal services in Austria and Poland has also been theoretically researched. The archetypal dimension of the organization of provision of housing and communal services in Ukraine is described. On the basis of the conducted theoretical research and practical experience it is proved that archetypal approaches to the organization of provision of housing and communal services in Ukraine are fundamentally different from the European countries. In Ukraine, by the year 2014, the procedure for the formation of prices and tariffs for electricity, gas supply, etc. was established by law. utilities. Namely, the National Commission for Energy Regulation and Utilities (NERCAP) is setting the threshold levels of prices in Ukraine for electricity, natural gas for the population, budget organizations and institutions, utility companies, and utilities tariffs. NKREKP acts in compliance with the Law of Ukraine "On Natural Monopolies", where "a natural monopoly is the state of the commodity market, in which the satisfaction of demand in this market is more effective in the absence of competition due to technological features of production (in connection with a significant reduction of production costs on unit of goods as production volumes increase), and goods (services) produced by subjects of natural monopolies can not be replaced by consumption of other goods (services), in connection with which the demand for this product line It depends less on the price changes for these goods (services) than the demand for other goods (services)".

It is proved that the vertical mechanism of forming the housing and communal services market is uncompetitive. High quality of provision of housing and communal services can be achieved only under conditions of free competition.

Keywords: sustainable development, organization of provision of communal services, formation of prices and tariffs, quality of life.

\section{АРХЕТИПНІ МОДЕЛІ СТАЛОГО РОЗВИТКУ КРАЇН: КОМПАРАТИВНИЙ АНАЛІЗ}

Анотація. Розглянуто основні ознаки збалансованого підходу до задоволення власних потреб з точки зору “сталого розвитку”. Наголошено, що організація надання комунальних послуг є базовою потребою кожного громадянина і, за концепцією раціональної бюрократії М. Вебера, має працювати на забезпечення потреб кожного громадянина. Підкреслено, що розвинені європейські країни значну увагу приділяють якості життя населення.

Так, місто Відень (Австрія) десятий рік поспіль займає першу позицію у рейтингу якості життя. Стисло розглянуто архетипний вимір формування 
якісної складової постачання комунальних послуг у розвинених країнах $\mathrm{C}_{\text {в- }}$ ропи. Серед них Німеччина, яка до 2006 року сформувала сучасний ринок надання якісних комунальних послуг на основі вільної конкуренції. Однією з особливостей організації ринку постачання житлово-комунальних послуг у Німеччині виявлено простоту переходу від одного надавача послуги до більш прийнятного. Виокремлено досвід Німеччини в облаштуванні й переоснащенні старих будинків “хрущовського” типу в Східному Берліні на престижні та елітні.

Сучасні підходи німецької якості розраховані на те, що з 2020 року Німеччина стане країною без “шкідливої енергіі”, тобто перейде на нові технології енергозбереження, що доступні людям середнього класу. Також теоретично досліджено ринок організації надання комунальних послуг в Австрії та Польщі. Схарактеризовано архетипний вимір організації надання житлово-комунальних послуг в Україні.

На основі проведеного теоретичного дослідження та практичного досвіду доведено, що архетипні підходи щодо організації надання житлово-комунальних послуг в Україні кардинально відрізняються від європейських країн. В Україні до 2014 року законодавчо закріпився порядок формування цін і тарифів на електроенергію, газопостачання та інші комунальні послуги. Встановлення граничних рівнів цін в Україні на електроенергію, природний газ для населення, бюджетних організацій і установ, підприємств комунальної теплоенергетики, тарифів на комунальні послуги здійснює Національна комісія з питань регулювання енергетики та комунальних послуг (НКРЕКП).

НКРЕКП діє на виконання Закону України “Про природні монополії”, де “природна монополія - стан товарного ринку, при якому задоволення попиту на цьому ринку є більш ефективним за умови відсутності конкуренції внаслідок технологічних особливостей виробництва (у зв'язку з істотним зменшенням витрат виробництва на одиницю товару в міру збільшення обсягів виробництва), а товари (послуги), що виробляються суб'єктами природних монополій, не можуть бути замінені у споживанні іншими товарами (послугами), у зв’язку з чим попит на цьому товарному ринку менше залежить від зміни цін на ці товари (послуги), ніж попит на інші товари (послуги)”.

Доведено, що вертикальний механізм формування ринку житлово-комунальних послуг є неконкурентноспроможним. Висока якість надання житлово-комунальних послуг може бути досягнута лише за умови вільної конкуренції.

Ключові слова: сталий розвиток, організація надання комунальних послуг, формування цін і тарифів, якість життя.

\section{АРХЕТИПНЫЕ МОДЕЛИ УСТОЙЧИВОГО РАЗВИТИЯ СТРАН: КОМПАРАТИВНЫЙ АНАЛІЗ}

Аннотация. Рассмотрены основные признаки сбалансированного подхода к удовлетворению собственных потребностей с точки зрения “устойчивого развития”. Отмечено, что организация предоставления коммунальных услуг 
является базовой потребностью каждого гражданина и, в соответствии с концепцией рациональной бюрократии М. Вебера, должна работать на обеспечение потребностей каждого гражданина. Подчеркнуто, что развитые европейские страны значительное внимание уделяют качеству жизни населения.

В частности, город Вена (Австрия) десятый год подряд занимает первую позицию в рейтинге качества жизни. Кратко рассмотрен архетипный подход к измерению формирования качественной составляющей коммунальных услуг в развитых странах Европы. Среди них Германия, которая до 2006 года сформировала современный рынок предоставления качественных коммунальных услуг на основе свободной конкуренции. Одной из особенностей организации рынка жилищно-коммунальных услуг в Германии выявлено простоту перехода от одного поставщика услуги к более приемлемому. Выделен опыт Германии в обустройстве и переоснащении старых домов “хрущевского” типа в Восточном Берлине на престижные и элитные.

Современные подходы немецкого качества рассчитаны на то, что с 2020 года Германия станет страной без “вредной энергии”, то есть перейдет на новые технологии энергосбережения, доступные людям среднего класса. Также теоретически исследован рынок организации предоставления коммунальных услуг в Австрии и Польше. Охарактеризован архетипный подход организации предоставления жилищно-коммунальных услуг в Украине.

На основе проведенного теоретического исследования и практического опыта доказано, что архетипные подходы к организации предоставления жилищно-коммунальных услуг в Украине кардинально отличаются от европейских стран. В Украине до 2014 года законодательно закрепился порядок формирования цен и тарифов на электроэнергию, газоснабжение и другие коммунальные услуги. Установление предельных уровней цен в Украине на электроэнергию, природный газ для населения, бюджетных организаций и учреждений, предприятий коммунальной теплоэнергетики, тарифов на коммунальные услуги осуществляет Национальная комиссия по вопросам регулирования энергетики и коммунальных услуг (НКРЕКП).

НКРЕКП действует во исполнение Закона Украины “О естественных монополиях", где “естественная монополия - состояние товарного рынка, при котором удовлетворение спроса на этом рынке является более эффективным при условии отсутствия конкуренции вследствие технологических особенностей производства (в связи с существенным уменышением расходов производства на единицу товара по мере увеличения объемов производства), а товары (услуги), производимые субъектами естественных монополий, не могут быть заменены в потреблении другими товарами (услугами), в связи с чем спрос на данном товарном рынке меньше зависит от изменения цен на эти товары (услуги), чем спрос на другие товары (услуги)”.

Доказано, что вертикальный механизм формирования рынка жилищнокоммунальных услуг является неконкурентоспособным. Высокое качество предоставления жилищно-коммунальных услуг может быть достигнуто при условии свободной конкуренции. 
Ключевые слова: устойчивое развитие, организация предоставления коммунальных услуг, формирования цен и тарифов, качество жизни.

Formulation of the problem. The modern development of Ukraine de monstrates many examples of real steps of integration into a developed world society. In particular, this is a joint effort of the authorities and the community to obtain Tomos on autocephaly by the Orthodox Church of Ukraine [1] and the adoption by the Verkhovna Rada of a bill on the consolidation of the strategic course for membership in the European Union and NATO [2] and the exclusion from the Transitional Provisions of the Constitution of an item that allowed the use of existing military bases on the territory of Ukraine for the temporary stay of foreign military formations on lease terms [2], and the Concept of Combating Terrorism in Ukraine [3] and Law on counteracting bullying [4]. These steps demonstrate the maturation and unanimity of the Ukrainian society in the correctness of the chosen path and leave no doubt about increasing the moral, cultural and professional components. However, business communication at the level of meeting the basic needs of the organization of providing high-quality communal services remains a problem.

The analysis of the recent publications on this topic shows that the issue of organizing the provision of high-quality communal services by the scholars was not systematically considered. More attention was paid to other components of the state and public administration. The modern scholars, namely: E. Afonin, V. Bodrov, V. Yev- dokimova, V. Knyazev, N. Nyzhnyk, S. Popov, Yu. Surmin, S. Seryogin and others. considering the issues of the public management adhere to the tendencies of human-centered orientation. The issue of the quality of communal services among scientists is given by the Candidate of Social Sciences, the Head of the Union of Housing Owners of Ukraine O. Kucherenko, the question of a comparative analysis of heat consumption in Ukraine and the world is considered by the Doctor of Technical Sciences, Professor V. Deshko with co-authors in 2008. Pricing for gas for domestic consumers is considered by T. Pilkevych. It should also be noted that the above issues are considered either by political organizations or lawyers (Prostopravo.com.ua). However, the theoretical developments of these issues slowly intersect with practice.

Therefore, the purpose of this work is a comparative analysis of the archetypal models of sustainable development of the countries in the field of providing quality communal services and encouraging further discussion.

Presentation of the main research material. In this paper the term "sustainable development" is considered from the point of view of the "Concept of Sustainable Development" proposed by Brundtland Commission, which worked from 1984 to 1987. From this standpoint the concept of "sustainable development" takes into account the satisfaction of human needs, the improvement of the welfare of the present 
generations and the preservation of resources for the future generations. That is, a balanced, non-detached approach to satisfaction of own needs.

The system of providing communal services worldwide is a prime location for meeting human needs.

The system of providing communal services, in a broad sense, can be called one of the components of the bureaucracy, which, according to the concept of rational bureaucracy of M. Weber, must work to meet the needs of each citizen.

According to the international consulting company Mercer in 2019 [5] (see Table 1), the highest place in the world in terms of quality of life rating is Vienna (Austria) for the tenth consecutive year. Of the 231 studied cities in the world Kyiv does not rank first. Luxembourg is named the safest city in the world.

The study also considered the quality of communal services in developed European countries. One of them is Germany. In Germany [6] by 2006 a modern market for quality communal services was formed. For electricity services: there are over 1000 electricity suppliers and more than 13000 electricity tariffs. As an incentive the suppliers constantly offer certain bonuses to the subscribers who have entered into an agreement with them. On the site CHECK24 the subscriber in a short period of time can choose the affordable capacity, tariff, read subscribers reviews on the quality of services provided and make his own choices. There are also certain conditions that a subscriber must fulfill. If the agreement is concluded for 12 months, the price for the consumed electricity will be fixed, regardless of whether the tariff increased during this time. If the subscriber at the end of the agreement has not switched to another provider of electricity supply, then the tariff for him will also increase. It is convenient that the subscriber's task is to only select a service provider on the site, and the entire procedure of disconnecting from the past service provider and connecting to the new service provider is the task of the organization chosen by the subscriber.

Table 1

Quality of life in cities around the world

\begin{tabular}{|c|l|l|}
\hline Rank & \multicolumn{1}{|c|}{ City } & \multicolumn{1}{c|}{ Country / Region } \\
\hline 1 & Vienna & Austria \\
\hline 2 & Zurich & Switzerland \\
\hline 3 & Vancouver & Canada \\
\hline 3 & Munich & Germany \\
\hline 3 & Auckland & New Zealand \\
\hline 6 & Dusseldorf & Germany \\
\hline 7 & Frankfurt & Germany \\
\hline 8 & Copenhagen & Denmark \\
\hline 9 & Geneva & Switzerland \\
\hline 10 & Basel & Switzerland \\
\hline
\end{tabular}


Regarding the gas supply: in Germany [6] since 2006 the subscriber chooses a supplier of gas at his own discretion. To compare gas tariffs the German subscribers can go to the CHECK24 site and knowingly choose a gas supplier in a few minutes. There are currently more than 825 gas suppliers in Germany. This approach ensures high quality of subscriber service and the ability to keep reasonable prices for gas service. Since in the case of raising prices or providing poor-quality services, the subscriber has the right to choose a new gas supplier.

The homeownership services in Germany are provided by the private companies whose responsibilities include the maintenance of the residential buildings, capital and current repairs of the buildings and public places.

Also interesting is the experience of Germany in the reconstruction and retrofitting of the old "Khrushchev" type buildings in East Berlin: communications are completely replaced by new and modern, the walls are insulated, the roof is new, equipped with built-in elevators, the doors in the entrances are replaced by glass and modern ones. Such housing in modern Germany has become prestigious and elite. It is also transformed into elite the old schools. This is evidenced by eyewitnesses, in particular, the staff of the University "Ukraine" after a business trip.
Since 2009 energy-independent homes built in Germany have become popular with new technologies using the energy of the Sun and the heat of the Earth for heating. Such houses are accessible to people of middle class. Such approaches are designed to ensure that Germany will become a country without "harmful" energy in the future [7]. The non-volatile construction standard becomes mandatory in Europe from 2020.

In this work the prices for the above services are not discussed, but we emphasize that a person who works is able to pay for the communal services.

Austria. Heating in new energy-efficient homes is cheaper. Table 2 shows the percentage that represents a certain operational service from the total amount of payment for the communal services.

There are many gas and electricity service providers in the Austrian communal services market. The subscriber only selects the service provider acceptable for himself, the connection is carried out by the organization itself. As a rule, the service providers offer profitable bonuses - several months of free use, reduced rates, etc.

The operational services of the Austrian market include:

- Central heating and hot water supply;

Table 2

Distribution of operating costs in $\%$ of the total

\begin{tabular}{|c|c|c|c|c|c|}
\hline 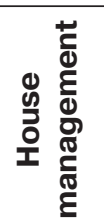 & 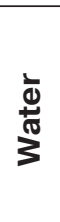 & 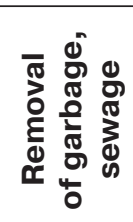 & 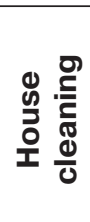 & 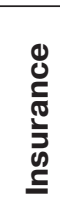 & 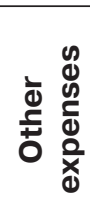 \\
\hline 16 & 16 & 11 & 25 & 26 & 6 \\
\hline
\end{tabular}


- Cold water supply and drainage;

- Sewerage and its cleaning, repair of pipes;

- Chimney sweeping;

- Removal of garbage, cleaning gutters and utilization of messy things;

- Disinsection, fight against insects and rodents;

- General lighting of the house, staircase, yard, including the cost of electricity, light bulbs, fuses;

- Compulsory insurance (from fire, water supply breakthrough, including corrosion);

- Voluntary insurance (from hurricane, beating of windows); for this type of insurance consent of most residents is required;

- Administrative expenses - by agreement;

- There may be additional costs for the communal services (laundry, sauna, swimming pool, etc.);

Replacing the supplier of gas or electricity is the same as in Germany.

It has its own peculiarities of provision of the communal services and a neighbor to Ukraine, Poland. One of these features is that the inhabitants of the apartment houses themselves cre- ate a community for the maintenance of the houses, such as the Ukrainian Association of co-owners of a multiapartment building. The staff of such a community consists only of the director and accountant. Electricians, plumbers, wipers are hired from thirdparty organizations that provide quality services. The trend is the abandonment of domestic gas and the transition to induction electric stoves. That is, the satisfaction of basic needs in quality communal services depends on the ability to unite the inhabitants of the house.

It should be noted that the new approaches to the organization of the communal services in developed countries have been systematically implemented since the middle of the last century. You can add to the list of the countries you have Denmark, Sweden, Finland, and others.

In Ukraine, the prices and tariffs are formed by the National Commission for Energy Regulation and Communal Services (NCERCS).

Applying an archetypal approach we will consider the origins of the above Commission (Table 3).

Table 3

An archetypal component of the formation of the Commission for the regulation of prices for the communal services in the Independent Ukraine

\begin{tabular}{|c|l|l|l|}
\hline Years & \multicolumn{1}{|c|}{ Basis } & \multicolumn{1}{|c|}{ Powers } & \multicolumn{1}{c|}{ Loss of validity } \\
\hline 1 & \multicolumn{1}{|c|}{2} & \multicolumn{1}{c|}{ 4 } \\
\hline $1991-$ & $\begin{array}{l}\text { Law № 507-XII of Decem- } \\
\text { ber 3, 1990 "On Prices and } \\
\text { Pricing" }\end{array}$ & $\begin{array}{l}\text { The basic principles of the es- } \\
\text { tablishment and application of } \\
\text { the prices and tariffs and the } \\
\text { organization of control over } \\
\text { their observance }\end{array}$ & $\begin{array}{l}\text { On the basis of the } \\
\text { Law of Ukraine of } \\
\text { June 21, 2012 "On } \\
\text { Prices and Pricing" } \\
\text { № 5007-VI }\end{array}$ \\
\hline 1994 & $\begin{array}{l}\text { Decree of the President of } \\
\text { Ukraine dated December } \\
\text { 8, 1994 № 738/94 "On the } \\
\text { National Commission for } \\
\text { Electricity Regulation" }\end{array}$ & $\begin{array}{l}\text { Formation of the pricing policy } \\
\text { for setting tariffs for electric } \\
\text { power, starting from April 1, } \\
\text { 1995 }\end{array}$ & $\begin{array}{l}\text { Decree of the Presi- } \\
\text { dent of Ukraine da- } \\
\text { ted November 23, } \\
\text { 2011 "On liquidation } \\
\text { of the National Elec- }\end{array}$ \\
\hline
\end{tabular}




\begin{tabular}{|c|c|c|c|}
\hline 1 & 2 & 3 & 4 \\
\hline & & & $\begin{array}{l}\text { tricity Regulatory } \\
\text { Commission of } \\
\text { Ukraine" }\end{array}$ \\
\hline 1997 & $\begin{array}{l}\text { Decree of the President of } \\
\text { Ukraine of August 19, } 1997 \\
\text { № } 853 \text { "On Measures to } \\
\text { Implement Government } \\
\text { Policy in the Sphere of Na- } \\
\text { tural Monopolies" }\end{array}$ & $\begin{array}{l}\text { Powers of the National Com- } \\
\text { mission that carries out state } \\
\text { regulation in the field of ener- } \\
\text { gy, is extended to the oil and } \\
\text { gas sector }\end{array}$ & In force \\
\hline 2011 & $\begin{array}{l}\text { Decree of the President } \\
\text { of Ukraine dated July } 8 \text {, } \\
2011 \text { № } 743 / 2011 \text { "On the } \\
\text { Establishment of the Na- } \\
\text { tional Commission for the } \\
\text { Regulation of the Com- } \\
\text { munal Services Market of } \\
\text { Ukraine" }\end{array}$ & $\begin{array}{l}\text { In compliance with the Law of } \\
\text { Ukraine № 1682-14 "On Natu- } \\
\text { ral Monopolies", tariffs for the } \\
\text { communal services are set }\end{array}$ & In force \\
\hline 2014 & $\begin{array}{l}\text { Decree of the President of } \\
\text { Ukraine dated September } \\
10,2014 \text { № } 715 / 2014 \text { "On } \\
\text { Approval of the Regulation } \\
\text { on the National Commis- } \\
\text { sion for State Regulation in } \\
\text { the Spheres of Energy and } \\
\text { Communal Services" }\end{array}$ & $\begin{array}{l}\text { State regulation of activity of } \\
\text { the subjects of natural mo- } \\
\text { nopolies and economic enti- } \\
\text { ties conducting activities in } \\
\text { adjacent markets in the fields } \\
\text { of electricity, heat, centralized } \\
\text { water supply and drainage, in } \\
\text { the markets of natural gas, oil } \\
\text { (associated) gas, gas (metha- } \\
\text { ne) of coal deposits and gas } \\
\text { of slate strata (hereinafter - } \\
\text { natural gas), oil and petroleum } \\
\text { products, as well as the pro- } \\
\text { cessing and disposal of the } \\
\text { household wastes }\end{array}$ & In force \\
\hline 2014 & $\begin{array}{l}\text { Decree of the President of } \\
\text { Ukraine dated August 27, } \\
2014 \text { No 694/2014 "On } \\
\text { the National Commission } \\
\text { for State Regulation in the } \\
\text { Spheres of Energy and } \\
\text { Communal Services" }\end{array}$ & $\begin{array}{l}\text { Powers of The National Com- } \\
\text { mission that carries out state } \\
\text { regulation in the field of ener- } \\
\text { gy has been extended to the } \\
\text { communal services (National } \\
\text { Commission for State regula- } \\
\text { tion in the fields of energy and } \\
\text { communal services) }\end{array}$ & In force \\
\hline
\end{tabular}

From the above table it is clear that effective in the absence of competition in Ukraine the prices and communal due to the technological features of proservices tariffs are formed in accor- duction (in connection with a signifidance with the Law of Ukraine "On cant reduction in production costs per Natural Monopolies".

"Natural monopoly - the state of the commodity market in which satisfaction of demand in this market is more unit of goods with increasing production), and goods (services) produced by the subjects of natural monopolies can not be replaced by consumption of 
other goods (services), therefore, the demand in this commodity market is less dependent on changes in prices for these goods (services) than the demand for other goods (services)" [8].

By 2014 the procedure for forming prices and tariffs for electricity, gas supply and other communal services was legally established in Ukraine. Namely, the National Commission for Energy Regulation and Communal Services (NCERCS) is setting the threshold levels of prices in Ukraine for electricity, natural gas for the population, budget organizations and institutions, communal services companies, and communal services tariffs.

NCERCS - a state collegiate body subordinated to the President of Ukraine and accountable to the Verkhovna Rada of Ukraine, the state regulatory body for energy and communal services. Regulatory powers of the Commission apply to electricity, gas, heat supply, water supply and drainage [9].

It should be emphasized that the Government of Ukraine has abandoned the bonuses and "over-the-counter payments" when signing a new agreement with the board of the "Naftogas" company [10].

From the Report of March 31, 2016 № 515 approved by the Resolution of the National Commission that carries out state regulation in the fields of energy and communal services "On the results of the activities of the National Commission that performs state regulation in the energy and communal services sectors in 2015", we see that "Indicators of the quality of electric energy (which is characterized by the level of voltage, frequency, overvoltage, etc.) today is defined in National Standards of Ukraine 13109-97 "Norms of quality of electric energy in general-purpose power systems" and National Standards of Ukraine EN 50160:2014 "Characteristics of power supply voltage in electric networks of general purpose". The powers of the Commission for monitoring and regulating the quality of the electric energy are not currently included" [9].

Concerning the quality of the communal services: at the end of 2018 the Cabinet of Ministers of Ukraine approved the "Procedure for checking the quality of the provision of certain communal services and management services for a multi-apartment house according to the parameters stipulated by the agreement on the provision of the relevant services" [11].

This Procedure determines the mechanism for carrying out the verification of compliance with the quality of the provision of services for the supply of heat energy, hot water supply, centralized water supply, centralized sewage disposal, domestic waste management in relation to the provision of services for the disposal of household waste (hereinafter referred to as communal services) and services for managing the multi-apartment house parameters, provided for in the agreement on the provision of the relevant services, in order to assess their compliance with the basic requirements for the quantity and quality and taking measures for the providing security and reliability when providing communal services and management services for a multi-apartment house.

In case of failure to provide, provision of incomplete or inadequate quality 
management services for a multi-apartment house or housing and communal services, the consumer and not less than two other consumers of the relevant service (living in neighbouring apartments) constitute an act of claim. The communal services provider or the manager of the multi-apartment house within five working days decides on the satisfaction of the requirements set forth in the act of claim, or provides the consumer with a substantiated written refusal.

The consumer also has the right to apply to the relevant authorized state authorities for the protection of the violated rights regarding the quality of communal services or management services for a multi-apartment house.

It should be noted that in Ukraine there are alternative opportunities for concluding agreements for electricity supply. In particular, the "Trade Electric Company" (TEC), a limited liability company, is the supplier of electric energy to consumers in Ukraine. But this company does not provide services to individual consumers.

Conclusions. From the study of the archetypal models of sustainable development of the countries we see that the organization of providing high-quality communal services is one of the important components of satisfaction of the basic human needs. From this component the sustainable development of the state depends on the whole. The countries that have addressed these basic issues are effectively developing, are at the highest levels in the quality of life rating and are among the countries of sustainable development.

In the countries of successful models of sustainable development the forma- tion of prices and tariffs for communal services is carried out with the help of a market mechanism which is not influenced by outside organizations. The prices are formed depending on demand and supply. Providing quality services is in higher demand.

In Ukraine a vertical model for pricing and tariffs for the communal services has been formed. The mechanism for checking the quality of provided housing and communal services is slow and bureaucratized. The consumer of housing and communal services, as a rule, has no alternative and is compelled to use the services of the only available provider of the given service.

The prospect of further research may be the consideration of alternative approaches to the organization of quality communal services in Ukraine.

\section{REFERENCES}

1. Usi predstavnyky Vselens'koho patriarkhatu pidpysaly Tomos dlia Ukrainy [All representatives of the Ecumenical Patriarchate signed Tomas for Ukraine]. (n.d.). pravda.com. ua/news/2019/01/9/7203315/. Retrieved from https://www.pravda.com. ua/news/2019/01/9/7203315/ [in Ukrainian].

2. Rada zakripyla $\mathrm{v}$ Konstytutsii kurs na YeS i NATO [The Council has established a course on the EU and NATO in the Constitution]. (n.d.). ukrinform.ua/rubric-polytics/2635688rada-zakripila-v-konstitucii-kursna-es-i-nato.html\#. Retrieved from https://www.ukrinform.ua/rubricpolytics/2635688-rada-zakripila-vkonstitucii-kurs-na-es-i-nato.html\# [in Ukrainian].

3. "Kontseptsiia borot'by z teroryzmom v Ukraini” zatverdzhena Ukazom Prezy- 
denta Ukrainy vid 5 bereznia 2019 roku № 53/2019 ["The Concept of the Fight against Terrorism in Ukraine" was approved by the Decree of the President of Ukraine of March 5, 2019, № 53/2019]. (n.d.). president.gov.ua/ documents/532019-26178. Retrieved from https://www.president.gov.ua/ documents/532019-26178 [in Ukrainian].

4. Zakon Ukrainy vid 18.12.2018 № 2657-VIII "Pro vnesennia zmin do deiakykh zakonodavchykh aktiv Ukrainy schodo protydii bulinhu (ts'kuvanniu)" [Law of Ukraine dated 18/12/2018 № 2657-VIII “On Amendments to Certain Legislative Acts of Ukraine on Combating Bullying (Hunt)"]. (2019, January 18). Holos Ukrainy. - Voice of Ukraine. 11 [in Ukrainian].

5. 2019 Quality of Living Ranking (n.d.). imercer.com/ Retrieved from https:// www.imercer.com/ [in Ukrainian].

6. Komunal'ni posluhy $\mathrm{v}$ Nimechchyni: scho vkhodyt', iak rozrakhuvaty i splatyty [Public utilities in Germany: what's included, how to calculate and pay] (n.d.). migrant.biz.ua/nimechina/ zhittya-de/komunalni-posluhy.html Retrieved from https://migrant.biz. ua/nimechina/zhittya-de/komunalniposluhy.html [in Ukrainian].

7. Enerhon ezalezhni budynky: koly bajduzhe, skil'ky koshtuie haz [Non-energy-dependent buildings: no matter how much gas costs] (n.d.). dw.com/ uk/\% D0\%B5\% D0\%BD\% D0\%B5 $\% \mathrm{D} 1 \% 80 \% \mathrm{D} 0 \% \mathrm{~B} 3 \% \mathrm{D} 0 \% \mathrm{BE} \% \mathrm{D} 0 \%$ BD\%D0\%B5\%D0\%B7\% D0\%B0\% D0\%BB\%D0\%B5\%D0\%B6\%D0\% BD\%D1\%96-\%D0\%B1\%D1\%83\% D0\%B $4 \%$ D0\%B8\%D0\%BD\%D0\% BA\%D0\%B $8-\%$ D0\%BA\%D0\%BE $\% \mathrm{D} 0 \% \mathrm{BB} \% \mathrm{D} 0 \% \mathrm{~B} 8-\% \mathrm{D} 0 \% \mathrm{~B} 1 \% \mathrm{D} 0-$ $\% \mathrm{~B} 0 \% \mathrm{D} 0 \% \mathrm{~B} 9 \% \mathrm{D} 0 \% \mathrm{~B} 4 \% \mathrm{D} 1 \% 83 \%$ D0\%B6\%D0\%B5-\%D1\%81\%D0\%B A\%D1\%96\%D0\%BB\%D1\%8C\%D0\%
BA\%D0\%B8-\%D0\%BA\%D0\%BE\% D1\%88\%D1\%82\%D1\%83\%D1\%94\% D $0 \%$ B $3 \%$ D $0 \%$ B $0 \%$ D $0 \%$ B $7 /$ a-4502813 Retrieved from https:// w w w. dw.com / u k / \% D $0 \%$ B $5 \%$ D0\%BD\%D0\%B5\%D1\%80\%D0\% B $3 \%$ D 0\%BE\% D0\%BD\% D0\%B5 $\%$ D0\%B7\%D0\%B0\%D0\%BB\%D0 $\%$ B5\%D0\%B6\%D0\%BD\%D1\%96$\%$ D0\%B1\%D1\%83\%D0\%B4\%D0\% B8\% D0\%BD\%D0\%BA\% D0\%B8$\%$ D $0 \%$ B A \% D $\%$ B E \% D 0 B B \% D0\%B8-\%D0\%B1\%D0\%B0\%D0\% B9\% D0\%B4\%D1\%83\%D0\%B6\% D0\%B5-\%D1\%81\%D0\%BA\%D1 $\% 96 \%$ D0\%BB\%D1\%8C\%D0\%BA $\%$ D0\%B8-\%D0\%BA\%D0\%BE\%D $1 \% 88 \%$ D $1 \% 82 \%$ D1\%83\%D1\%94$\%$ D $0 \%$ B $3 \%$ D $0 \%$ B $0 \%$ D $0 \%$ B $7 /$ a 4502813 [in Ukrainian].

8. Zakon Ukrainy vid 20 kvitnia 2000 roku № 1682-III "Pro pryrodni monopolii" [Law of Ukraine dated April 20, 2000 № 1682-III “On Natural Monopolies”]. (2000, May 24). Uriadovyj kur'ier. - Government Courier [in Ukrainian].

9. Zvit pro rezul'taty diial'nosti Natsional'noi komisii, scho zdijsniuie derzhavne rehuliuvannia $\mathrm{u}$ sferakh enerhetyky ta komunal'nykh posluh, u 2015 rotsi [Report on the results of the activities of the National Commission for State regulation in the fields of energy and utilities in 2015] (n.d.). nerc.gov.ua/?id=19733 Retrieved from http://www.nerc.gov.ua/?id=19733 [in Ukrainian].

10. Uriad maie try bazovi umovy schodo novoho kontraktu z pravlinniam kompanii "Naftohaz" [The Government has three basic conditions for a new contract with the board of "Naftogaz"] (n.d.). facebook.com/ volodymyrgroysman/? tn $=\mathrm{kCH}$ R \& e i d = A R C - I S 0 Y k 7 p Z x Aj1FTXUcy6-IlWfEOS5JqRAtfQJ0zqne0txWDnc4UPpHsG5e0Xo_ 
ewJO7X0Wlnsn7\&hc_ref=ARSzy bn6Jo2fuxMJWhxnJG8̄hNIt6uSyY S5mmZ6g5F2_SutQkon7sbDi08zTR_AwSW5c\&fref $=$ nf Retrieved from https://www.facebook.com/ volodymyrgroysman/? tn $=\mathrm{kCH}$ $\mathrm{R} \& \mathrm{e} \mathrm{id}=\mathrm{A} \mathrm{R}$ C - I S $\overline{0 \mathrm{Y}} \mathrm{k} \overline{7 \mathrm{p}} \mathrm{Zx}$ Aj1FTXUcy6-IlWfEOS5JqRAtfQJ0zqne0txWDnc4UPpHsG5e0Xo_ ewJO7X0Wlnsn7\&hc ref $=$ ARSzyb n6Jo2fuxMJWhxnJG8h̄it6uSyYS5 mmZ6g5F2_SutQkon7sbDi08zTR_ AwSW5c\&fref=nf [in Ukrainian].

11. Postanova KMU vid 27 hrudnia 2018 roku № 1145 "Pro zatverdzhennia Poriadku provedennia perevirky vidpovidnosti iakosti nadannia deiakykh komunal'nykh posluh ta posluh z upravlinnia bahatokvartyrnym budynkom parametram, peredbachenym dohovorom pro nadannia vidpovidnykh posluh" [Resolution of the CMU dated December 27, 2018, № 1145 “On approval of the procedure for checking the quality of the provision of certain communal services and services for management of a multi-apartment building to the parameters stipulated by the agreement on the provision of the relevant services"]. (2019, January 5). Uriadovyj kur'ier. - Government Courier [in Ukrainian].

\section{СПИСОК ВИКОРИСТАНИХ ДЖЕРЕЛ}

1. Усі представники Вселенського патріархату підписали Томос для України [Електронний ресурс]. Режим доступу : https://www.pravda. com.ua/news/2019/01/9/7203315/

2. Рада закріпила в Конституції курс на СС i НАТО [Електронний ресурс]. - Режим доступу: https://www.ukrinform.ua/rubricpolytics/2635688-rada-zakripila-vkonstitucii-kurs-na-es-i-nato.html\#
3. “Концепція боротьби 3 тероризмом в Україні” затверджена Указом Президента України від 5 березня 2019 року № 53/2019 [Електронний ресурс]. - Режим доступу : https://www.president.gov.ua/ documents/532019-26178

4. Закон України від 18.12.2018 № 2657-VIII “Про внесення змін до деяких законодавчих актів України щодо протидії булінгу (цькуванню)” // Голос України. 2019. № 11. -18 січ.

5. 2019 Quality of Living Ranking [Електронний ресурс]. - Режим доступу : https://www.imercer.com/

6. Комунальні послуги в Німеччині: що входить, як розрахувати і сплатити [Електронний ресурс]. - Peжим доступу : https://migrant.biz. ua/nimechina/zhittya-de/komunalniposluhy.html

7. Енергонезалежні будинки: коли байдуже, скільки коштує газ [Електронний ресурс]. - Режим доступу : https://www.dw.com/uk/\%D0\%B5\% D0\%BD\%D0\%B5\% D1\%80\%D0\% B3\% D0\%BE\%D0\%BD\%D0\%B5 $\%$ D0\%B7\% D0\%B0\% D0\%BB\%D0 $\%$ B5\%D0\%B6\%D0\%BD\%D1\%96$\% \mathrm{D} 0 \% \mathrm{~B} 1 \% \mathrm{D} 1 \% 83 \% \mathrm{D} 0 \% \mathrm{~B} 4 \% \mathrm{D} 0 \%$ B8\%D0\%BD\%D0\%BA\%D0\%B8$\%$ D 0 B A \% D 0\% BE \% D \% B B \% D0\%B8-\%D0\%B1\%D0\%B0\%D0\% B9\% D0\%B4\% D 1\%83\% D0\% B6\% D0\%B5-\%D1\%81\%D0\%BA\%D1 $\% 96 \%$ D0\%BB\% D1\%8C\%D0\%BA $\%$ D0\%B8-\%D0\%BA\%D0\%BE\%D $1 \% 88 \% \mathrm{D} 1 \% 82 \% \mathrm{D} 1 \% 83 \% \mathrm{D} 1 \% 94-$ $\%$ D $0 \%$ B 3\% D0\% B 0\% D 0\%B $7 / \mathrm{a}-$ 4502813

8. Закон України від 20 квітня 2000 р. № 1682-III "Про природні монополії // Урядовий кур’єр. - 2000. 24 трав.

9. Звіт про результати діяльності Національної комісіі, що здійснює державне регулювання у сферах енерге- 
тики та комунальних послуг, у 2015 році [Електронний ресурс]. - Режим доступу : http://www.nerc.gov. ua/?id=19733

10. Уряд має три базові умови щодо нового контракту з правлінням компанії “Нафтогаз” [Електронний ресурс]. - Режим доступу : https:// www.facebook.com/ volod y m y r g roy s m a n / ? tn $=\mathrm{kCH}$-R\&eid $=$ ARC-ISOYk $\overline{7}$ Zx-_Aj1FTXUcy6-IlWfEOS5JqRAtfQJ0zqne0txWDnc4UPpHsG5e0Xo ewJO7X0Wlnsn7\&hc_ref=ARSzy $\bar{b}$
n6Jo2fuxMJWhxnJG8hNIt6uSyYS5 mmZ6g5F2_SutQkon7sbDi08zTR AwSW5c\&fref $=\mathrm{nf}$

11. Постанова КМУ від 27 грудня 2018 року № 1145 “Про затвердження Порядку проведення перевірки відповідності якості надання деяких комунальних послуг та послуг з управління багатоквартирним будинком параметрам, передбаченим договором про надання відповідних послуг" // Урядовий кур'єр. - 2019. - № 3. 5 січ. 